\title{
EARNING MANAGEMENT DAN CASH HOLDING SEBAGAI MODERASI PENDETEKSIAN WINDOW DRESSING DENGAN F-SCORE ANALYSIS
}

\author{
Niken Savitri Primasari ${ }^{1}$, Endah Tri Wahyuningtyas ${ }^{2}$ \\ Program Studi Akuntansi, Fakultas Ekonomi dan Bisnis \\ Universitas Nahdlatul Ulama Surabaya \\ niken@unusa.ac.id \\ endahtri@unusa.ac.id
}

\begin{abstract}
This research aims to carry out financial report detection and the possibility of window dressing practice with earning management and cash holding leading to the fraudulent financial reporting actions in companies listed on the Indonesia Stock Exchange. Financial statements will be classified according to Altman Z-Score. Action of window dressing is reporting with F-Score, the subsequent treatment of earning management and cash holding as a moderating are to find out the influence of two window dressings to F-Score. The period of research on financial statements will be conducted on a triwulanly basis from 2015-2019.
\end{abstract}

Keywords: Earning Management, Cash Holding, Window Dressing, F-Score

\section{Intisari}

Penelitian ini bertujuan untuk melakukan deteksi laporan keuangan dan kemungkinan praktik Window dressing dengan manajemen produktif dan kepemilikan kas yang mengarah pada tindakan pelaporan keuangan palsu di perusahaan yang terdaftar di Bursa Efek Indonesia. Laporan Keuangan akan diklasifikasikan menurut Altman Z-score. Tindakan Window dressing adalah pelaporan dengan F-Score, perlakuan berikutnya manajemen produktif dan memegang kas sebagai moderator adalah untuk mengetahui pengaruh dua jendela dressing ke F-score. Periode penelitian dilakukan secara triwulanan dari 2015-2019.

Kata kunci: Earning Management, Cash Holding, Window Dressing, F-Score

\section{PENDAHULUAN}

\subsection{Latar Belakang Masalah}

Pada triwulan awal tahun 2019, fenomena temuan adanya perlakuan window dressing pada pelaporan keuangan mulai bermunculan, diawali dengan AISA, lalu GIAA dan JakPro. Pelaporan keuangan yang seharusnya memberikan informasi yang akurat, transparan dan reliable disinyalir disalahgunakan dengan melakukan strategi pencatatan keuangan tertentu, terutama sejak investor dan masyarakat mampu menginterpretasikan informasi yang diberikan oleh rasio-rasio keuangan yang mencerminkan posisi kekayaan dan kinerja 
perusahaan. Penyalahgunaan terhadap laporan keuangan tersebut umum dilakukan pada akhir tahun dan disajikan dalam prospektus tahunan perusahaan. Hal ini sesuai dengan penelitian yang dilakukan oleh Bestari (2014) dan Yusniati (2015). Fraudulent financial reporting biasanya terjadi dengan bentuk falsification dari laporan keuangan untuk memperoleh keuntungan atau overstatement posisi kekayaan dan kinerja perusahaan (Nia, 2015).

Meningkatnya kecurangan mengindikasikan terdapatnya kebutuhan yang tinggi dalam penelitian untuk menemukan metode yang efektif dalam mendeteksi potensi kecurangan pada perusahaan (Dalnial et al., 2014). Salah satu cara yang digunakan untuk mendeteksi kecurangan pada laporan keuangan adalah dengan menggunakan rasio keuangan. Adapun rasio-rasio yang relevan dengan posisi kekayaan dan kinerja perusahaan tersebut akan diproksikan oleh perubahan nilai rasio total asset turnover, debt to total asset, net profit margin, earning pershare, price earnings dan harga saham. Hal ini sesuai dengan penelitian terdahulu meneliti pengaruh leverage, profitability, asset composition, liquidity, dan capital turnover terhadap fraudulent financial reporting pada perusahaan Bursa Malaysia (Zainudin dan Hashim, 2016).

Hasil past financial reporting yang terbaca dengan analisa rasio mendorong manajemen untuk melakukan kecurangan dengan window dressing, yang umumnya dilakukan manajemen dengan menyajikan laporan keuangan yang lebih baik dari keadaan yang sesungguhnya untuk memperbaiki penampilan kinerja. Perlakuan window dressing ini diproksikan dengan earning management dan cash holding yang mengarah pada tindakan fraudulent financial statement yang akan ditunjukkan dengan nilai F-Score model sebagai suatu ukuran yang diklaim dapat digunakan untuk mendeteksi salah saji material dalam laporan keuangan dengan tingkat keakuratan antara 68-70\% (Dechow et al., 2011).

\subsection{Permasalahan Penelitian}

Berdasarkan latar belakang di atas, maka pertanyaan penelitian adalah sebagai berikut :

1. Apakah Past Financial Performance berpengaruh terhadap F-Score ?

2. Apakah Past Financial Performance berpengaruh terhadap Earning Management ?

3. Apakah Past Financial Performance berpengaruh terhadap Cash Holding ?

4. Apakah Past Financial Performance dengan moderasi tindakan Earning Management dan Cash Holding akan berpengaruh terhadap F-Score? 


\subsection{Tujuan Penelitian}

Berdasarkan pertanyaan di atas, maka tujuan dari penelitian ini adalah untuk :

1. Melakukan deteksi pengaruh Past Financial Performance terhadap F-Score

2. Melakukan deteksi pengaruh Past Financial Performance terhadap Earning Management.

3. Melakukan deteksi pengaruh Past Financial Performance terhadap Cash Holding

4. Melakukan deteksi pengaruh Past Financial Performance dengan moderasi tindakan Earning Management dan Cash Holding terhadap F-Score

\subsection{Manfaat Penelitian}

Penelitian ini diharapkan dapat memberikan tambahan konseptual literatur pada akademisi, terutama di bidang ilmu manajemen keuangan dan akuntansi, yang dapat digunakan sebagai kontribusi praktis bagi organisasi, terutama sebagai salah satu cara melakukan akuntansi dan keuangan pasar bursa dalam upaya-upaya mengurangi tindakan window dressing yang mengarah pada fraudulent financial reporting.

\section{TINJAUAN PUSTAKA}

\subsection{Penelitian Terdahulu}

Kecurangan pelaporan keuangan dapat dilakukan dengan cara menyajikan laporan keuangan yang overstatement ataupun understatement. Kecurangan pelaporan keuangan yang dilakukan dengan cara menyajikan laporan keuangan lebih baik dari kondisi sebenarnya lebih banyak dijumpai daripada yang menyajikan lebih buruk dari kondisi sebenarnya (Sihombing, 2014). Beberapa cara untuk melakukan overstatement dalam laporan keuangan, adalah, 1) Overstating revenues, 2) Overstating sales, 3) Pengungkapan laporan keuangan yang tidak tepat (improper disclosures) seperti tidak diungkapkannya kewajiban kontingensi atau kejadian negatif lainnya.

Menurut Karyono (2013) pendeteksian atas kecurangan pelaporan keuangan dilakukan dengan cara membandingkan hasil analisis atas laporan keuangan dengan laporan periode sebelumnya. Cara pendeteksian atas kecurangan pelaporan keuangan adalah 1) analisis vertikal, 2) analisis horisontal, 3) analisis rasio.

Berbagai cara dilakukan untuk mendeteksi kecurangan, menurut Association of 
Certified Fraud Examiners (ACFE) antara lain dengan menggunakan rasio keuangan. Rasio keuangan merupakan alat untuk mengukur hubungan antara nilai item-item dalam laporan keuangan. Penelitian yang dilakukan oleh Zainudin dan Hashim (2016) membuktikan bahwa rasio keuangan yang terdiri dari leverage, profitabilitas, komposisi aset, likuiditas dan perputaran modal dapat digunakan untuk mendeteksi kecurangan pelaporan keuangan. Penelitian yang dilakukan Nia (2015) memberikan bukti empiris bahwa rasio perputaran modal dan profitabilitas, dapat memprediksi fraudulent financial reporting (FFR).

Kanda (2014) telah melakukan penelitian mengenai Window Dressing In Financial Practices, Hasil dari penelitian ini menunjukkan berbagai pihak seperti perusahaan perdagangan, rumah bisnis, penyedia dana, investor, menggunakan praktek window dressing untuk tujuan mereka masing-masing. Seperti untuk menarik investor, untuk mengurangi kewajiban pajak mereka dan lain-lain. Alasan utama dibalik penggunaan tersebut adalah keberadaan dalam kompetisi berlebih. Menurut Gumanti (2000) earning management diduga muncul atau dilakukan oleh manajer atau para pembuat laporan keuangan dalam proses pelaporan keuangan suatu organisasi karena mereka mengharapkan suatu manfaat dari tindakan yang dilakukan. Bukti empiris menunjukkan bahwa earning management atau manajemen laba telah dijadikan sebagai sumber target dalam proses penilaian prestasi usaha suatu departemen.

Widya (2014) telah melakukan penelitian dengan topik analisis window dressing pada perusahaan sektor industri barang konsumsi. Permasalahan yang diangkat adalah apakah perusahan-perusahaan industri barang konsumsi memiliki cash holding yang lebih tinggi pada kuartal 4 dibanding kuartal 1, kuartal 2 dan kuartal 3 pada tahun 2010 - 2013. Hasil dari penelitian yang dilakukan adalah perusahan-perusahaan industri barang konsumsi memiliki cash holding yang lebih tinggi pada kuartal 4 dibanding kuartal 1, kuartal 2 dan kuartal 3 pada tahun 2010 - 2013 dan perusahaan-perusahaan industri barang konsumsi terindikasi melakukan upward window dressing pada tahun 2010 - 2013.

Tindakan earning management dan cash holding merupakan bentuk salah satu dari fraudulent financial reporting yang dihitung dengan F-Score sebagai suatu ukuran yang diklaim dapat digunakan untuk mendeteksi salah saji material dalam laporan keuangan (Sukrisnadi, 2010). Fscore diperkenalkan oleh Dechow et al. (2012). Berdasarkan penelitian Dechow et al. (2012) F-Score model memiliki tingkat keakuratan antara 68-70\% tergantung 
dari kasus fraud yang terjadi. Komponen pada F-Score meliputi dua hal, yaitu accrual quality yang diproksikan dengan RSST dan financial performance yang diproksikan dengan perubahan pada akun piutang, perubahan pada akun persediaan, perubahan pada akun penjualan tunai, perubahan pada EBIT. Model F-Score merupakan penjumlahan dari dua variabel yaitu kualitas akrual dan kinerja keuangan. Perusahaan dapat dikatakan melakukan fraud apabila F-Score perusahaan tersebut lebih dari satu.

\subsection{Kerangka Konsep Penelitian}

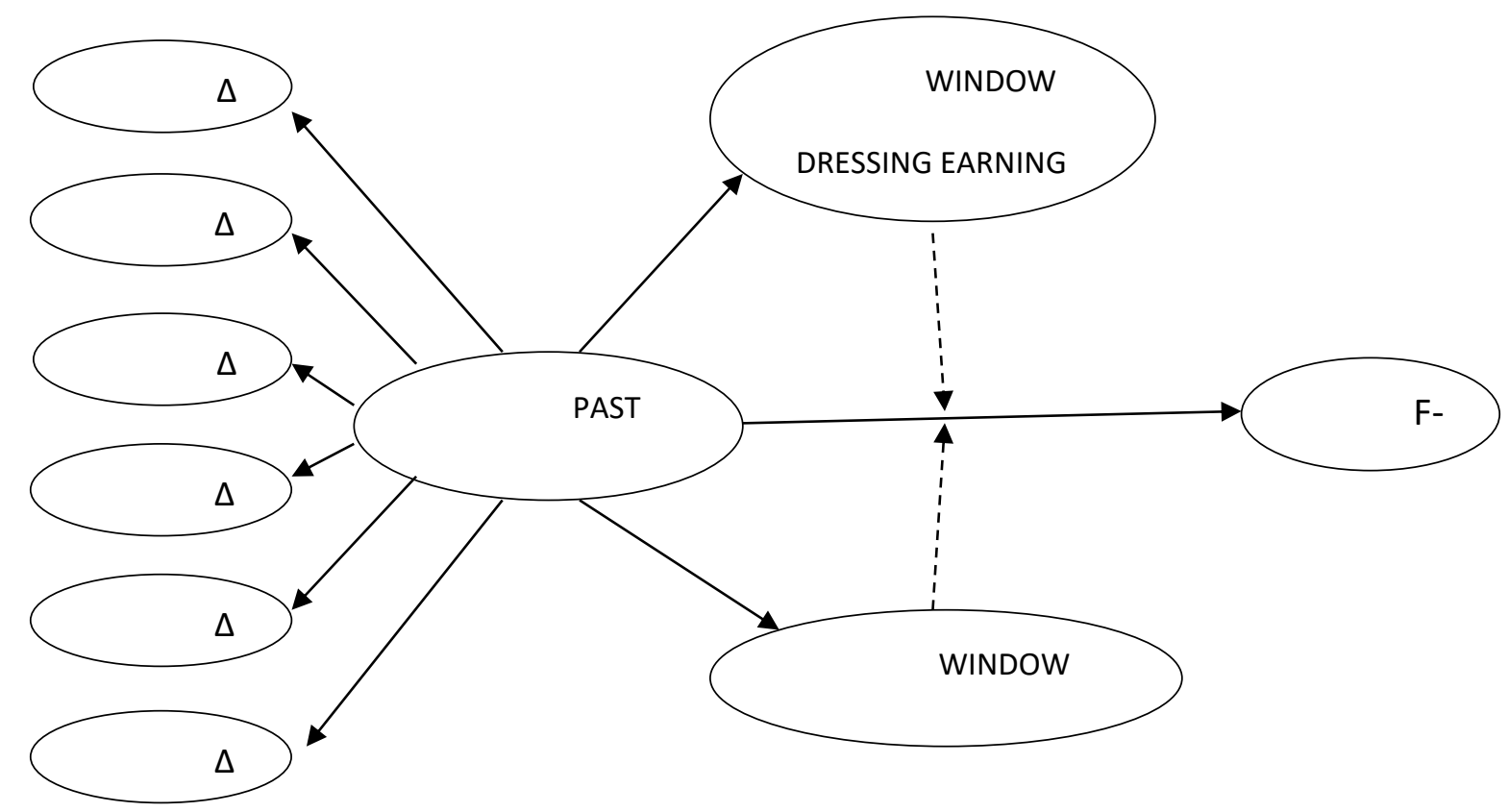

\subsection{Pengembangan Hipotesis}

\section{Past Financial Performance dengan Fraudulent Financial Reporting F-Score}

Meningkatnya temuan salah saji, baik itu overstatement maupun understatement pada laporan keuangan akhir tahun, akan menyebabkan kejanggalan dalam pergerakan past financial performance yang diwakili oleh rasio-rasio keuangan suatu perusahaan. Berdasarkan hal tersebut, salah satu cara yang dapat digunakan untuk mendeteksi kecurangan pada laporan keuangan adalah dengan menggunakan rasio-rasio keuangan, terutama rasio leverage, rasio profitabilitas dan likuiditas. Rasio leverage, profitability, liquidity, dan capital turnover memiliki pengaruh positif pada potensi fraudulent financial reporting (Widyanti dan Nuryanto, 2018). Maka hipotesis dalam penelitian ini adalah sebagai berikut, 
H1 : Past Financial Performance berpengaruh positif terhadap Fraudulent Financial Reporting

H2 : Past Financial Performance berpengaruh negatif terhadap Fraudulent Financial Reporting

\section{Past Financial Performance terhadap tindakan window dressing Earning Management}

Salah satu praktik window dressing laporan keuangan adalah dengan dengan melakukan manipulasi laba atau yang lebih dikenal dengan nama manajemen laba (earnings management) dengan maksud untuk dapat menunjukkan kinerja yang baik (Aprillia, 2015), oleh karena itu hipotesis berikutnya dalam penelitian ini adalah sebagai berikut,

H1 : Past Financial Performance berpengaruh positif terhadap tindakan window dressing earning management

H2 : Past Financial Performance berpengaruh negatif terhadap tindakan window dressing earning management

\section{Past Financial Performance terhadap tindakan window dressing Cash Holding}

Laporan keuangan yang merupakan dasar untuk menilai kinerja perusahaan dan membantu stakeholder dalam membuat keputusan (Marhamah, 2013). Berdasarkan hal tersebut perusahaan memiliki dorongan melakukan window dressing pada aset lancar agar terlihat bagus, yaitu dengan melaporkan cash holding yang lebih tinggi daripada sebenarnya pada akhir tahun (Bestari, 2014). Oleh karena itu hipotesis selanjutnya adalah sebagai berikut :

H1 : Past Financial Performance berpengaruh positif terhadap tindakan window dressing Cash Holding

H2 : Past Financial Performance berpengaruh negatif terhadap tindakan window dressing Cash Holding

Past Financial Performance dengan moderasi tindakan window dressing Earning Management dan Cash Holding terhadap F-Score

Kecurangan pelaporan keuangan yang dilakukan dengan cara menyajikan laporan keuangan earning overstated (Sihombing, 2014). Pendeteksian atas kecurangan pelaporan keuangan 
dapat dilakukan dengan cara membandingkan hasil analisis atas laporan keuangan dengan laporan periode sebelumnya (Karyono, 2013). F-Score adalah suatu ukuran yang dapat digunakan untuk mendeteksi salah saji material dalam laporan keuangan (Dechow et.al., 2012). Selanjutnya, Cash holding didefinisikan sebagai kas yang dimiliki perusahaan. Berdasarkan teori agensi, adanya konflik antara manajer dan pemegang saham menimbulkan keinginan manajemen untuk melakukan cash holding di perusahaan agar kinerja perusahaan terlihat baik dimata pemegang saham (Mambraku, 2014). Perlakuan cash holding oleh manajemen akan menimbulkan tindakan perataan laba yang kemudian akan mengarah pada tindakan salah saji laporan keuangan (Yusniati, 2015). Berdasarkan hasil penelitian terdahulu tersebut, maka hipotesa selanjutnya dalam penelitian ini adalah,

H1 : Past Financial Performance berpengaruh positif akibat moderasi tindakan window dressing Earning Management dan Cash Holding pada F-Score

H2 : Past Financial Performance berpengaruh negatif akibat moderasi tindakan window dressing Earning Management dan Cash Holding pada F-Score

\section{METODE PENELITIAN}

Populasi yang akan digunakan adalah seluruh perusahaan non-keuangan yang secara konsisten masih terdaftar di Bursa Efek Indonesia selama tahun 2015 sampai dengan tahun 2019. Sehingga terhitung jumlah sampel yakni sebanyak 856 data perusahaan tercatat. Penelitian ini dilakukan pada situasi lingkungan riil dengan unit analisis perusahaan publik yang berasal dari data sekunder yang bersifat transparan. Data sekunder terdapat pada web data perpustakaan Bursa Efek Indonesia (TICMI) dan IDX. Laporan keuangan perusahaan yang akan digunakan berasal dari laporan keuangan pada triwulan ketiga dan laporan keuangan tahunan. Sebagai upaya untuk memperoleh hasil obyektifitas yang optimal atas penelitian, maka sebelum menguji keterkaitan antara variabel bebas dengan variabel moderasi dan variabel terikatnya, pengklasifikasian kondisi keuangan perusahaan akan dilakukan dengan metode Altman Z-Score.

Selanjutnya pengujian akan diawali dengan uji asumsi klasik. Pengujian kolmogorovsmirnov untuk uji normalitas data, uji multikolinearitas dengan melihat nilai tolerance dan variance inflation factor, lalu uji heteroskedastisitas dengan uji glejser dan auto korelasi 
durbin watson test. Setelah lulus uji asumsi klasik, analisis regresi linier berganda akan dilakukan untuk menguji pengaruh antara variabel independen dan dependen, yang dilanjutkan dengan pengujian moderated regression analysis (MRA) dengan software SPSS.

Hasil tersebut akan mengindikasikan pada hasil pengujian hipotesis pengaruh signifikansi variabel independen terhadap variabel dependen dan perlakuan variabel independen dengan moderasi terhadap variabel dependen. Variabel independen yang diteliti adalah past financial performance yang berasal dari laporan keuangan triwulan ketiga yang diproksikan dengan perubahan nilai rasio Total Asset Turnover, Debt to Total Asset, Net Profit Margin, Earning Pershare, Price Earning Ratio dan Harga Saham dengan dua variabel moderasi, yakni window dressing dengan tindakan Earning Management dan window dressing dengan tindakan Cash Holding. Adapun variabel dependen yang diteliti adalah fraudulent financial reporting yang akan diproksikan dari nilai F-Score (Dechow, 2011).

Tahapan dalam diagram alir penelitian ini, akan dimulai dengan tahap awal yang terdiri dari,

(1) Studi Pendahuluan dengan mengumpulkan beberapa berita yang terkait dengan perusahaan go-publik di Indonesia sepanjang tahun 2015 - 2019.

(2) Menemukan fenomena dan gap yang terjadi pada lingkup akuntansi dan keuangan perusahaan yang terdaftar di Bursa Efek Indonesia.

(3) Setelah menemukan fenomena dan gap, selanjutnya penelitian dapat melakukan identifikasi dan merumuskan masalah atas fenomena dan gap yang terjadi.

(4) Dari rumusan masalah tersebut, tujuan penelitian dapat dirumuskan yakni untuk,

i. Mendeteksi deteksi pengaruh Past Financial Performance terhadap F-Score

ii. Mendeteksi pengaruh Past Financial Performance terhadap Earning Management.

iii. Mendeteksi pengaruh Past Financial Performance terhadap Cash Holding

iv. Mendeteksi pengaruh Past Financial Performance dengan moderasi tindakan Earning Management dan Cash Holding terhadap F-Score

(5) Setelah menentukan tujuan penelitian, tahap berikutnya yakni melakukan studi literatur yang berasal dari sudut teoritis dan penelitian-penelitian terdahulu.

(6) Selanjutnya, pengumpulan data sekunder laporan keuangan perusahaan go-publik nonkeuangan periode 2015 - 2019 dilakukan. Adapun data laporan keuangan yang akan digunakan adalah data laporan keuangan Q1 sampai dengan Q4. Data Q1 hingga Q3 
digunakan untuk mengolah Financial Ratio as Past Performance. Data laporan keuangan Q4 diolah dengan window dressing dan F-Score.

(7) Pada tahap berikutnya, adalah melakukan analisis data atas hasil olah tersebut. Analisis data akan dilakukan dengan menggunakan Pengujian akan diawali dengan analisis regresi linier berganda untuk menguji hubungan antara variabel independen dan dependen, yang dilanjutkan dengan pengujian moderated regression analysis (MRA) dengan software SPSS. Selanjutnya, melakukan pembahasan dari analisis dan interpretasi data.

(8) Tahap terakhir, kesimpulan dan saran bagi akademisi

\section{HASIL DAN PEMBAHASAN}

HASIL UJI SAMPLE PAIRED t-Test

Tabel 1.1

Uji t-Test Variabel Ratio Past Performance terhadap F-Score sebagai bentuk pendeteksian Fraudulent Financial Reporting

\begin{tabular}{lccc}
\hline \multirow{2}{*}{ Output } & \multicolumn{3}{c}{ Data Perbandingan } \\
\cline { 2 - 4 } & Q1 dan Q4 & Q2 dan Q4 & Q3 dan Q4 \\
\hline N & 378 & 378 & 378 \\
Korelasi & 0,882 & 0,781 & 0,811 \\
t-test & 1.110 & 1,003 & 1,233 \\
df & 370 & 370 & 370 \\
Sig. (2-tailed) & 0,724 & 0,630 & 0,557 \\
\hline
\end{tabular}

Berdasarkan data pada tabel 1.1, menunjukkan bahwa nilai uji-t untuk perbandingan data 1,110 keuangan masa lalu kinerja kuartal nilai uji-t untuk perbandingan data kinerja masa lalu keuangan kuartal kedua dengan data kuartal 1,003 dan t Nilai uji untuk perbandingan data kinerja keuangan masa lalu Triwulan 3 dengan data triwulan 4 adalah 1,233 setiap nilai signifikansi lebih besar dari $\alpha(0,05)$. Oleh karena itu, Ho diterima dan Ha ditolak sehingga dapat dinyatakan bahwa tidak ada perbedaan yang signifikan antara data variabel keuangan triwulan, 2 dan 3 triwulan dari data variabel kinerja keuangan 
triwulan tiga triwulan sebelumnya untuk F- Score sebagai pendeteksi terjadinya Fraudulent Financial Reporting.

Tabel 1.2

Uji t-Test Variabel Ratio Past Performance terhadap Nilai Earning Management sebagai bentuk pendeteksian Fraudulent Financial Reporting

\begin{tabular}{lccc}
\hline Output & \multicolumn{3}{c}{ Data Perbandingan } \\
\cline { 2 - 4 } & Q1 dan Q4 & Q2 dan Q4 & Q3 dan Q4 \\
\hline N & 378 & 378 & 378 \\
Korelasi & 0,770 & 0,697 & 0,732 \\
t-Test & 2,822 & 1,873 & $-0,463$ \\
df & 370 & 370 & 370 \\
Sig. (2-tailed) & 0,000 & 0,033 & 0,501 \\
\hline
\end{tabular}

Data pada tabel 1.2 menunjukkan bahwa perbandingan data variabel manajemen laba perusahaan (EM) pada kuartal pertama dengan data kuartal ke-4 sebesar 2,822 dan nilai uji-t untuk perbandingan data variabel EM pada kuartal 2 dengan data kuartal 4 sebesar 1,873, sedangkan nilai t-test untuk perbandingan data variabel EM's of Triwulan 3 dengan data kuartal ke-4 adalah -0,463. Nilai signifikan hasil t-test antara hasil nilai rasio past performing analysis dengan Earning Management di kuartal 1 dan 2 dengan nilai kuartal 4, terjadi signifikan hasil. Nilai signifikan terkuat terjadi pada nilai kuartal 1 dengan nilai kuartal ke 4, berikutnya baru terjadi tingkat signifikasi EM kuartal keempat dengan perbandingan nilai pada kuartal kedua. Hal ini dimungkinkan, karena manajemen perusahaan melakukan targeting performance di setiap tahunnya. Sebaliknya, tidak ada perbedaan yang signifikan antara data ukuran perusahaan variabel Triwulan 3 dengan data variabel EM Triwulan 4 yang berarti mengindikasikan saat itu suatu kemungkinan terjadinya window dressing, terutama karena hampir sebagian besar perusahaan yang termasuk dalam sampel penelitian ini merupakan perusahaan yang melakukan ekspor-impor, kemungkinan terjadinya perbedaan dikarenakan fluktuasi valuta asing sebagai bagian dari pendapatan ataupun pengeluaran perusahaan adalah sangat dimungkinkan karena Juli hingga September adalah term bulan pembayaran piutang dagang eksportir dan hutang dagang importir wajib terselesaikan (terbayar). 
Tabel 1.3

Uji t-Test Variabel Ratio Past Performance terhadap Nilai Cash Holding sebagai bentuk pendeteksian Fraudulent Financial Reporting

\begin{tabular}{lccc}
\hline \multirow{2}{*}{ Output } & \multicolumn{3}{c}{ Data Perbandingan } \\
\cline { 2 - 4 } & Q1 dan Q4 & Q2 dan Q4 & Q3 dan Q4 \\
\hline $\mathrm{N}$ & 378 & 378 & 378 \\
Korelasi & 0,901 & 0,949 & 0,835 \\
$\mathrm{~T}$ & $-0,657$ & 0,331 & $-0,577$ \\
$\mathrm{df}$ & 370 & 370 & 370 \\
Sig. (2-tailed) & 0,853 & 0,987 & 0,623 \\
\hline
\end{tabular}

Data dalam tabel 1.3 menunjukkan bahwa perbandingan data variabel Cash Holding perusahaan $(\mathrm{CH})$ pada kuartal pertama dengan data kuartal keempat -0,657 dan nilai uji-t untuk perbandingan data variabel $\mathrm{CH}$ dari kuartal 2 dengan data triwulan 4 sebesar 0,331, sedangkan nilai uji-t untuk perbandingan data variabel $\mathrm{CH}$ untuk Triwulan 3 dengan data triwulan ke-4 adalah -0,577. Oleh karena itu, Ho diterima dan Ha ditolak sehingga dapat dinyatakan bahwa tidak ada perbedaan yang signifikan antara variabel data cash holding triwulan 1, 2 atau variabel data cash holding triwulan 3 dengan variabel data cash holding triwulan 4.

Tabel 1.4

Uji t-Test Variabel Ratio Past Performance dengan Nilai Earning Management dan Cash Holding sebagai Moderasi nilai pendeteksian Fraudulent Financial Reporting

\begin{tabular}{lccc}
\hline \multirow{2}{*}{ Output } & \multicolumn{3}{c}{ Variabel } \\
\cline { 2 - 4 } & PFP & EM & CH \\
\hline $\mathrm{N}$ & 378 & 378 & 378 \\
Koefisien & 0,334 & 0,439 & 0,223 \\
$p$-value & 0,771 & 0,043 & 0,833 \\
\hline
\end{tabular}


Data dalam tabel 1.4 menunjukkan bahwa kinerja keuangan masa lalu (PFP) yang lebih mempengaruhi moderasi yakni adanya tindakan Earning Management dengan garis koefisien 0,439 dan p-value 0,043. Ini menjelaskan bahwa manajemen laba dilakukan sebagai tindakan para manajer perusahaan untuk memastikan bahwa kinerja perusahaan selalu memperoleh hasil keuangan maksimal dengan minimal targeting yakni performa keuangan di tahun sebelumnya. Hal ini mengindikasikan bahwa perusahaan bertanggungjawab atas modal dari sebagian investornya dengan selalu memberikan sinyal yang baik bagi investor.

\section{KESIMPULAN}

Penelitian ini menunjukkan bahwa:

1. Tidak ada perbedaan yang signifikan antara data variabel keuangan 1 kuartal, 2 dan 3 kuartal dari data variabel kinerja keuangan (past financial performance) triwulanan tiga kuartal sebelumnya untuk F-Score sebagai Fraudulent Financial Reporting.

2. Tidak ada perbedaan yang signifikan antara data variabel ukuran perusahaan Triwulan 3 dengan data variabel EM Triwulan 4 yang berarti ada indikasi terjadinya window dressing yang disebabkan oleh aktifitas ekspor-impor dari perusahaan-perusahaan tersebut.

3. Tidak ada perbedaan yang signifikan antara variabel data Past Financial Performance triwulan 1,2 dan 3 dengan variabel data cash holding triwulan 4.

4. Namun, untuk kinerja keuangan masa lalu (PFP) adalah pengaruh tindakan EM dengan garis koefisien 0,439 dan p-value 0,043 .

Sehingga dapat disimpulkan bahwa perusahaan sektor non-perbankan yang terdaftar di BEI pada 2015-2019 tidak diindikasikan melakukan praktik window dressing dari kinerja keuangan masa lalu mereka meskipun ada beberapa alasan manajemen pendapatan menyimpulkan sebagai moderasi untuk F-Score. Ini menjelaskan bahwa manajemen laba dilakukan sebagai tindakan untuk memastikan kinerja perusahaan keuangan dan target mereka selalu memiliki sinyal yang baik bagi investor mereka.

\section{DAFTAR PUSTAKA}

ACFE. (2016). Report To The Nations on Occupational Fraud and Abuse.

Apriliana, Shindy Virgin. 2016. Analisis Window Dressing pada Perusahaan Badan Usaha 
Milik Negara yang Terdaftar di Bursa Efek Indonesia Periode 2012-2014. STIE Perbanas.

Bestari, Widya Ayu. 2014. Analisis Window Dressing pada Perusahaan Sektor Industri Barang Konsumsi yang Terdaftar di Bursa Efek Indonesia Periode 2010-2013. Program Studi Akuntansi, Fakultas Ekonomi Universitas Maritim Raja Ali Haji. Tanjungpinang.

Dalnial, H., Kamaluddin, A., Sanusi, Z. M., \& Khairuddin, K. S. (2014). Detecting Fraudulent Financial Reporting through Financial Statement Analysis, 2(1), 17-22.

Dechow, P. M, Hutton, A. P, Kim, J H, and Sloan, R. G.( 2012). Detecting Earning Management: A New Approach. Journal of Accounting Reserach, Vol. 50, Ed. 2, Hal. 275-334.

Kanda, R. 2013. Window Dressing in Financial Practices, IES Management College and Research Centre, Mumbai.

Karyono. 2013. Forensic Fraud. Yogyakarta: CV. Andi.

Mambraku, Milka Erika. 2014. Pengaruh Cash Holding dan Struktur Kepemilikan Manajerial Terhadap Income Smoothing. Skripsi. Fakultas Ekonomika dan Bisnis Universitas Diponegoro.

Marhamah. 2013. Pengaruh Manajemen Laba, Ukuran Kinerja Perusahaan Terhadap Corporate Social Responbility (CSR) dan Nilai Perusahaan pada Perusahaan Manufaktur yang Tercatat di Bursa Efek Indonesia Tahun 2007-2010. Jurnal STIE Semarang. Vol 5. No. 3. (ISSN : 2252-7826).

Nia, S. H. 2015. Financial ratios between fraudulent and non-fraudulent firms : Evidence from Tehran Stock Exchange, 7(March), 38-44.

Sihombing, Kennedy Samuel dan Rahardjo, Shiddiq Nur. 2014. Analisis Fraud Diamond dalam Mendeteksi Financial Statement Fraud: Studi Empiris pada Perusahaan Manufaktur yang Terdaftar di Bursa Efek Indonesia (BEI) Tahun 2010- 2012. Diponegoro Journal of Accounting Vol. 03 No. 02. ISSN (Online): 2337-3806.

Sukrisnadi, D. 2010. Pemakaian Ukuran F-Score dalam Kasus-Kasus Salah Saji Laporan Keuangan di Pasar Modal Indonesia.

Widyanti, Tyas dan Muhammad Nuryanto. 2018. Analisis Rasio Keuangan sebagai Deteksi Kecurangan Laporan Keuangan Perusahaan Barang Konsumsi yang Terdaftar di Bursa Efek Indonesia. Jurnal Akuntansi dan Pendidikan Vo.7 No.1, 72-80.

Yusiyanti, Hindun, Negina Kencono dan Eliada Herwiyanti. November 2015. Analisis Window Dressing Perusahaan Go Public Sektor Infrastruktur, Utilitas, dan 
Transportasi di Indonesia. Telaah Manajemen Fakultas Ekonomi dan Bisnis Universitas Jenderal Soedirman. Vol. 10, No. 2.

Zainudin, E. F., \& Hashim, H. A. 2016. Detecting fraudulent financial reporting using financial ratio. Journal of Financial Reporting and Accounting, 14(2), 266-278. 